\title{
Biological therapy penetration for inflammatory bowel disease in Latin America: current status and future challenges
}

\author{
Abel Botelho QUARESMA ${ }^{1,2}$, Claudio Saddy Rodrigues COY ${ }^{3}$, Aderson Omar Mourão Cintra DAMIÃ ${ }^{4}$, \\ Gilaad G KAPLAN ${ }^{5}$ and Paulo Gustavo KOTZE ${ }^{2}$
}

Received 1/7/2019

Accepted 16/7/2019

\begin{abstract}
Background - The introduction of anti-TNF agents represented a landmark in the management of both Crohn's disease (CD) and ulcerative colitis (UC), with improved efficacy and safety when compared with conventional treatment. However, significant challenges still exist in Latin America to facilitate the access of biological agents for physicians and patients. Objective - The aim of this review was to summarize current evidence on penetration of biological agents for CD and UC in Latin America. Methods - Data are derived from a previous complete systematic review that explored different characteristics of inflammatory bowel diseases (IBD) in Latin America. The studies fully included in this previous systematic review which contained detailed descriptions of the percentage of use of biological agents in different cohorts throughout Latin American and Caribbean countries were included, and descriptive findings were compiled, describing CD and UC penetration of these drugs in different patient cohorts from different countries. Results - From the 61 studies included in the original systematic review, only 19 included data of the percentage of patients treated with biological agents. Anti-TNF use in CD varied from 1.51\% in Mexico up to $46.9 \%$ in Colombia, with most of the studies describing anti-TNF use in approximately $20 \%-40 \%$ of CD patients. On the other side, the frequency of the use of biologics was clearly lower in UC, varying from $0 \%$ in 2009 to up 16.2\% in 2018, according to two different Mexican studies. Only two studies described the penetration of anti-TNF agents in IBD overall: $13.4 \%$ in a Colombian and $37.93 \%$ in a Brazilian study. No studies described percentage of use of new biologic agents (vedolizumab and ustekinumab). Conclusion - Penetration of anti-TNF agents in Latin America is comparable to the rest of the world in CD, but lower in UC. With the increase in the incidence and prevalence of IBD, specific strategies to increase access to anti-TNF agents in UC and new biological agents overall are warranted. HEADINGS - Crohn disease. Ulcerative colitis. Inflammatory bowel disease. Biological therapy. Latin America.
\end{abstract}

\section{INTRODUCTION}

The incidence of inflammatory bowel diseases (IBD), namely Crohn's disease (CD) and ulcerative colitis (UC) seems to be stabilized in the Western world and may be increasing in newly industrialized countries ${ }^{(1)}$. A recent systematic review demonstrated the growing incidence and prevalence of IBD in Latin America, a continent with few registries and population-based studies in the field ${ }^{(2)}$. IBD patients in Latin America seem to have a similar phenotype to those described in North America or Europe, but variations in patient care may be expected for different socioeconomical reasons.

The introduction of anti-TNF agents represented a landmark in the management of both CD and UC, with improved efficacy and safety when compared with conventional treatment ${ }^{(3-6)}$. Novel therapies, such as new biologic agents with different mechanisms of action (vedolizumab and ustekinumab) or small molecules (tofacitinib) targeting intestinal inflammation were recently approved and currently complete the therapeutic armamentarium to treat $\mathrm{IBD}^{(7-10)}$. Moreover, the development of different treatment strategies (such as early use of combined immunossupression and the treat-to-target approach) also contributed to better outcomes to our patients ${ }^{(11-13)}$.

There is variation in the frequency of use of biological agents in IBD worldwide. This is a consequence of different factors, such as physicians' experience, access to medication in public and private health systems, local regulatory issues, and continued medical education processes that also vary in different regions of the globe. Currently, as biologics represent the most effective therapy to achieve better outcomes in IBD, it is possible that the frequency of use of these agents can be directly related to different outcomes, such as reduction in abdominal surgery and hospitalizations. Thus, it is essential to understand the current status of biologic penetration in the therapeutic armamentarium in a determined region, to draft a current snapshot that might lead to an improvement in the quantity of patients treated and in the efficacy of biologics' use, aiming better patient care and outcomes.

There are descriptions of the efficacy and safety of anti-TNF agents in Latin America ${ }^{(14-16)}$. However, to date, there is scarce data on the precise penetration and frequency of use of biological agents 
in the management of IBD in our continent. Within this scenario, the aim of this review was to summarize data regarding frequency of use of biologic agents in the continent, determining its possible consequences on IBD care and speculating future directions to improve the current scenario on the use of these agents.

\section{METHODS}

This is a descriptive review. Extracted data were derived from a previous complete systematic review performed by three of the authors (AOMCD, GGK and PGK) that explored different characteristics of IBD in Latin America ${ }^{(2)}$. Studies were initially captured in three different databases, PUBMED, EMBASE and SCIELO. There was no language limitation (studies in English, Portuguese and Spanish were included). After abstract review, potential studies were analysed in detail as full text reviews. The studies fully included in this previous systematic review which contained detailed descriptions of the percentage of use of biological agents (biologicals' penetration) in different cohorts throughout Mexico, Central America, Caribbean and South America were included, and descriptive findings were compiled into a table, separating $\mathrm{CD}$ and UC penetration of these drugs in different patient cohorts from different countries.

\section{RESULTS}

The flowchart of the selection of the studies is published elsewhere ${ }^{(2)}$. We identified 1,434 articles that fulfilled the selection criteria: 255 from MEDLINE, 722 from EMBASE and 457 from SciELO. After abstract review, 83 articles were selected for full-text review. From the 61 studies included in the original systematic review, only 19 included data of the percentage of patients treated with biological agents. From those, all included only use of the first approved anti-TNF agents (infliximab [IFX] and adalimumab [ADA]). There were no studies to date including the frequency of use of most recently approved anti-TNF agents (e.g., golimumab and certolizumab pegol) or biologics with different mechanisms of action (e.g., vedolizumab or ustekinumab). Overall, studies mostly described cohorts of IBD patients, with four being performed exclusively in $\mathrm{CD}^{(17-20)}$ and two exclusively in UC patients ${ }^{(21,22)}$.

TABLE 1 describes in detail the current status of the frequency of use of biologics in different countries from Latin America, in $\mathrm{CD}$, UC or IBD overall. As seen, a clear variation was observed. The anti-TNF use in CD varied from $1.51 \%$ in Mexico up to $46.9 \%$ in Colombia. In addition to the aforementioned Mexican study, a study from Cuba (3.8\%), one from Brazil (4.8\%) and one from Puerto Rico (9.7\%) similarly had low biologic penetrations in pa-

TABLE 1. Studies from Latin America that described the frequency of biologics use (anti-TNF agents).

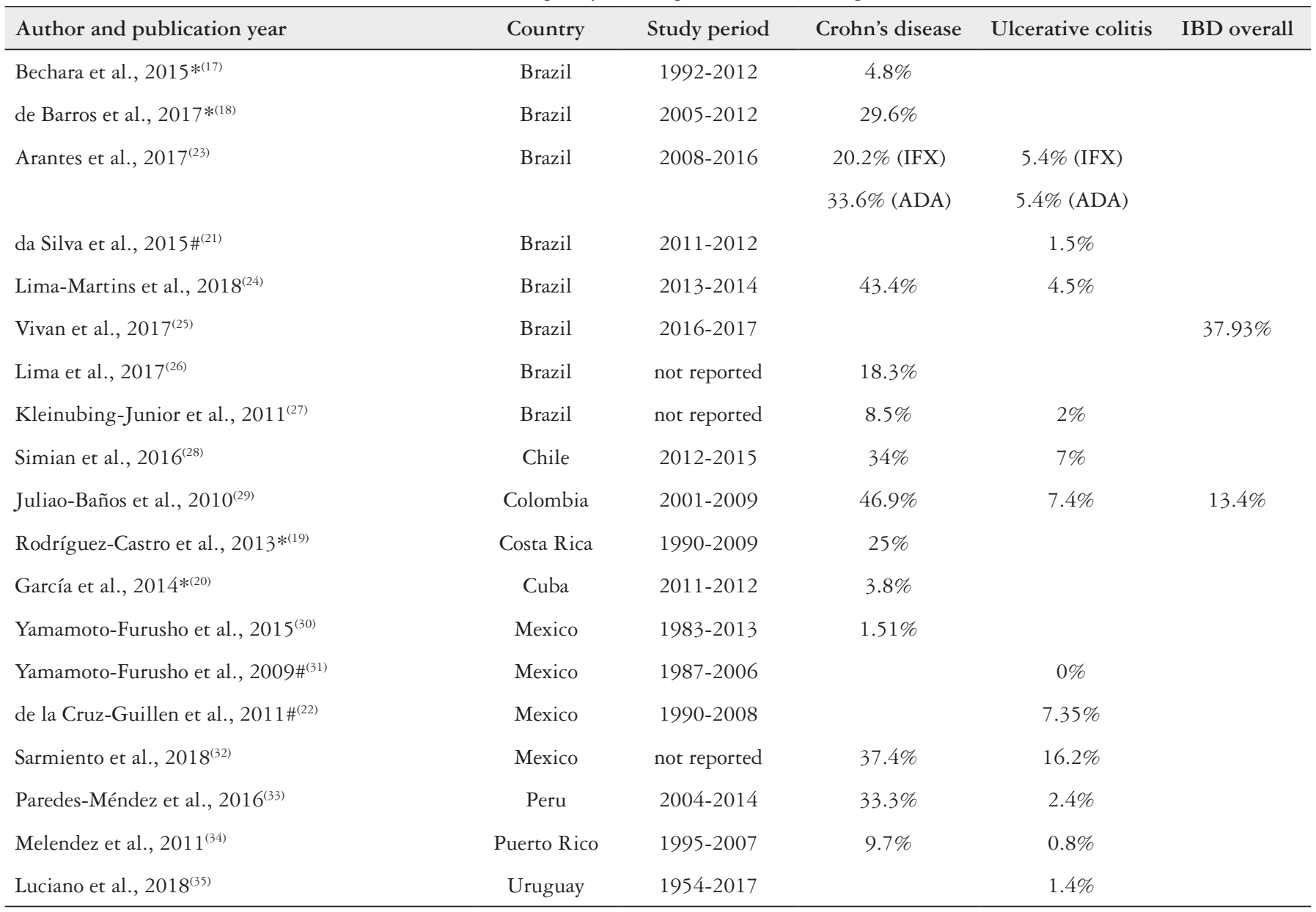

*Studies in exclusive Crohn's disease population. \#Studies in exclusive ulcerative colitis population. IBD: inflammatory bowel diseases; IFX: infliximab; ADA: adalimumab. 
tient care for CD. However, most of the studies described anti-TNF use in approximately $20 \%-40 \%$ of CD patients. On the other side, the frequency of use of biologics was clearly lower in UC, varying from $0 \%$ in 2009 to up $16.2 \%$ in 2018 , according to two different Mexican studies. Only two studies described the penetration of antiTNF agents in IBD overall: $13.4 \%$ in a Colombian and $37.93 \%$ in a Brazilian study. Only one study described data separately according to the anti-TNF agent employed. Arantes et al. demonstrated more adalimumab patients in $\mathrm{CD}$ as compared to infliximab, and equal use of both agents in UC ${ }^{(23)}$. FIGURE 1 summarizes the variation of biologic penetration in Latin American and Caribbean countries in $\mathrm{CD}$ and $\mathrm{UC}$ in two different maps.

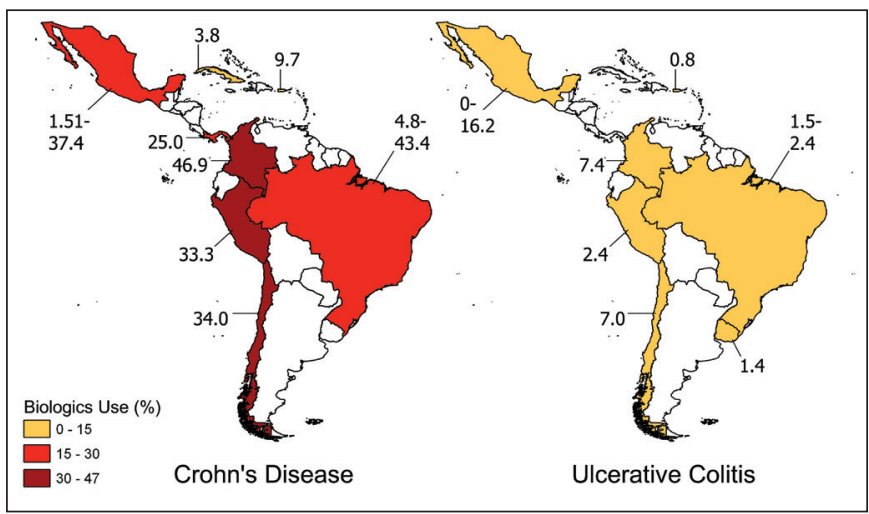

FIGURE 1. Geographical distribution of countries which reported anti-TNF penetration in CD and UC, with minimum and maximum frequencies reported.

\section{DISCUSSION}

The biologic penetration of anti-TNF agents (mostly IFX and ADA) in Latin America appears comparable with other regions of the world in $\mathrm{CD}$, but it is lower than what has been described in $\mathrm{UC}^{(36-39)}$. One possible reason to justify the findings described in this review is that anti-TNF agents were approved earlier for the management of CD than for UC globally. IFX was approved for UC in most Latin American countries between 2006-2008, and ADA had its approval from local regulatory agencies circa 2014. However, reimbursement for the use of anti-TNF agents for UC remains still a challenge in several countries in our continent. As an example, reimbursement for any biologic for UC in Brazil, the largest country in Latin America, is still not available in the public market even in 2019. The use of biologics to treat UC remains restricted for patients from specific private health insurance companies and few litigation actions in the public scenario. Hence, burocratic issues occurring in some Latin American health systems constitute a key factor to justify lower biologic penetration in UC as compared to $\mathrm{CD}$.

The lower use of anti-TNF agents in UC may have deleterious effects in patient care over the continent. By not achieving full control of disease activity, patients will probably be undertreated, consequently having more hospitalizations and steroid use. Surgical rates may also remain unchanged if no access to biological therapy is achieved. Our previous systematic review demonstrated that the crescent use of anti-TNF agents in CD was accompanied by a decrease in major abdominal surgical rates, what possibly reflected a better treatment algorithm. A similar pattern was not observed in
$\mathrm{UC}$, as the low biologic penetration in the continent remained low over the years, not reducing rates of colectomy ${ }^{(2)}$. This will certainly lead to several implications in health care structures and costs.

With approval and overspread use of anti-TNF biosimilars, it is expected that more patients can be treated with biologics in a near future. This can improve even more the access to this class of therapy for CD patients and increase the use in UC. With cost reduction from biosimilars, a more rapid approval of reimbursement for biologics in UC can be expected, and one can anticipate a change in the current scenario in certain Latin American countries like Brazil, where the public reimbursement for UC still is lacking. Nevertheless, although regulation specific to biosimilars has increased in Latin America countries in recent years, much progress remains to be made if standards, transparency, and licensing decisions are to be considered. Furthermore, pharmacovigilance programs for biosimilars represent an urgent and unmet need for most Latin America nations ${ }^{(40)}$. The experience with new biologics, such as vedolizumab and ustekinumab will also certainly be increased over the next years. Moreover, pricing will play an important role in positioning these agents in therapeutic algorithms of naive patients who need biological therapy.

In addition, close cooperation between study groups, public health authorities and patient associations are needed in order to improve access to anti-TNF agents in Latin America. Specific study groups like GEDIIB (Grupo de Estudos de Doenças Inflamatórias Intestinais Brasileiro) from Brazil or GADECCU (Grupo Argentino de Enfermedad de Crohn y Colitis Ulcerosa) from Argentina have a relevant role in demonstrating local epidemiological data to the public system aiming therapeutic protocols for better IBD care as a whole. PANCCO (Pan American Crohn's and Colitis Organization) has also contributed to aglutinate different countries from the region aiming scientific activities and spreading of knowledge in Latin America. The role of these entities in the continent will be crucial in order to facilitate access to medications by joining patients, physicians and payors into the discussion of accessing biologics in IBD.

As previously stated, no descriptions of use of certolizumab pegol in CD or golimumab in UC were described to date in Latin America. As there are scarce data in Latin America analysing the newer biologic agents with different mechanisms of action (anti-integrins and anti-interleukins), one should expect that penetration of these agents is surely lower than IFX and ADA in our continent. To date, there are no descriptions of frequencies of patients using these new agents in full cohort studies in Latin America. However, some initial experiences with the drugs are starting to be described, mostly in abstract form presented in recent IBD meetings ${ }^{(41-44)}$.

An initial Brazilian experience with 90 patients (52 with CD and 38 with UC using vedolizumab (VEDO), an anti-integrin agent, was described in $2018^{(41,42)}$. Clinical remission rates in CD after 52 weeks of treatment were $46.15 \%$ and $24.48 \%$ in as observed and NRI (non-responder imputation) analyses, respectively. Mucosal healing was observed in $36.11 \%(13 / 36)$ patients. In UC, clinical remission rates after 52 weeks in LOCF and NRI analyses, respectively, were $41.17 \%$ and $18.42 \%$. Mucosal healing was observed in $43.40 \%(13 / 30)$ of the patients. These results from a Brazilian multicentric cohort, mostly performed in refractory patients (only 13 of the 90 patients were previously naive to anti-TNF agents), demonstrate efficacy of VEDO in Latin America in similar rates from real world cohort studies from different parts of the globe. 
Data coming from Colombia, presented at the ECCO (European Crohn's and Colitis Organisation) 2019 meeting, from the EXVEDOCOL multicentric cohort study, demonstrated similar results with VEDO ${ }^{(43)}$. In total, 38 patients (31 with UC and only 7 with $\mathrm{CD}$ ) were included in the analysis. Overall, 23 from the 31 patients were previously exposed to anti-TNF agents. At week 14, clinical response was observed in $92 \%$ of UC and in $83 \%$ of $\mathrm{CD}$ patients. Clinical response rates were higher in patients who were naive to previous biologics $(92 \%)$ as compared to biologic refractory patients $(88 \%)$. Deep remission (mucosal healing and complete clinical remission) was observed in $46 \%$ of the patients. No detailed data on definitions of clinical response and remission were available in the abstract. These data deserve further interpretation and one should await the final publication with more details for more solid conclusions.

A single experience with Ustekinumab (UST) was described by a Brazilian group at the ECCO meeting in 2019 $9^{(44)}$. Forty-four patients with $C D$ were included in a real-world observational study from five academic practices in Brazil, between November 2017 and October 2018. Most of the patients received maintenance doses of $90 \mathrm{mg}$ every 8 weeks, after intravenous induction of $\sim 6 \mathrm{mg} / \mathrm{kg}$. After induction, $38.6 \%$ of patients achieved clinical remission. A significant drop in C-reactive Protein (CRP) and faecal calprotectin was also noticed after 16 weeks. After 44 weeks, clinical remission was observed in $75 \%$ of the patients (after 5 th dose). Two patients stopped the drug due to non-response. These were the first efficacy findings of UST in a Latin American country in the management of $\mathrm{CD}$.

As seen, the use of new biological agents such as VEDO and UST is scarce in Latin America, due to recent approval of the medications added to certain difficulties in access to the drug in the private and public market. Since VEDO and UST were only recently approved in some countries in the region, it is still expected that the frequency of use of anti-TNF might be higher in the continent, as compared to these new agents. Surely the overspread use and higher penetration of new biological agents may be a question of time in Latin America.
In conclusion, biologic penetration for $\mathrm{CD}$ in Latin America is comparable with other regions of the world. The same is not observed in UC. The increase in IBD incidence, as well as the significant investment in the development of new drugs and continuous medical education, have increased disease awareness among physicians in Latin America. Improvements in diagnosis and more effective treatment strategies with biologics have also raised the bar of expectation from both physicians and patients' perspectives. It is well established that biological therapy has changed the course of the disease and the access of these medications by public and/or private systems contributed for better outcomes in Latin American IBD patients. This could be better noticed in CD and it is still a current need in the management of UC in most Latin American countries. The role of medical entities is also key to integrate patients and payors to facilitate access to those effective medications. The crescent use of biosimilars will also help enhance biologic penetration in IBD in Latin America by reduction of costs, opening future possibilities to increase the number of treated patients with a fixed budget. Integration of health care payors, physicians and patients in the discussion of accessing biologics in IBD is essential to improve patient care in IBD.

\section{Authors' contribution}

Quaresma AB, Coy CSR and Kotze PG designed the review. Damião AOMC, Kaplan GG and Kotze PG collected data from previously pyblished systematic review as authors. Kotze PG, Damião AOMC and Quaresma AB drafted the paper. All authors gave important intellectual contribution and reviewed the final version of the manuscript.

\section{Orcid}

Abel Botelho Quaresma. Orcid: 0000-0002-3985-7402.

Claudio Saddy Rodrigues Coy. Orcid: 0000-0002-0916-4138.

Aderson Omar Mourão Cintra Damião. Orcid: 0000-00017584-7351.

Gilaad G. Kaplan. Orcid: 0000-0003-2719-0556.

Paulo Gustavo Kotze. Orcid: 0000-0002-2053-5315.

Quaresma AB, Coy CSR, Damião AOMC, Kaplan GG, Kotze PG. Frequência de utilização da terapia biológica para doenças inflamatórias intestinais na América Latina: situação atual e desafios futuros. Arq Gastroenterol. 2019;56(3):318-22.

RESUMO - Contexto - A introdução dos agentes anti-TNF representou um marco no tratamento da doença de Crohn (DC) e da recocolite ulcerativa (RCU), com maior eficácia e segurança quando comparado ao tratamento convencional. No entanto, ainda existem desafios significativos na América Latina para facilitar o acesso dos agentes biológicos a médicos e pacientes. Objetivo - O objetivo desta revisão foi reunir as evidências atuais sobre a penetração de agentes biológicos para DC e RCU na América Latina. Métodos - Os dados são derivados de uma revisão sistemática previamente publicada que explorou diferentes características das doenças inflamatórias intestinais (DII) na América Latina. Os estudos incluídos nesta revisão sistemática anterior que continham descrições detalhadas da percentagem do uso de agentes biológicos em coortes de pacientes em diferentes países da América Latina e Caribe foram incluídos, e os achados descritivos foram compilados detalhando a penetração destes medicamentos no manejo das DII. Resultados - Dos 61 estudos incluídos na revisão sistemática original, apenas 19 incluíram dados de percentagem de pacientes tratados com agentes biológicos. O uso de anti-TNF na DC variou de 1,51\% no México até 46,9\% na Colômbia, com a maioria dos estudos descrevendo o uso em aproximadamente $20 \%-40 \%$ dos pacientes na DC. Por outro lado, a frequência do uso de biológicos foi claramente menor na RCU, variando de $0 \%$ em 2009 a 16,2\% em 2018, de acordo com dois estudos mexicanos. Apenas dois estudos descreveram a penetração de agentes anti-TNF nas DII em geral: 13,4\% em estudo colombiano e 37,93\% em outro estudo brasileiro. Nenhum estudo descreveu o percentual de uso de novos agentes biológicos (vedulizumabe e ustekinumabe). Conclusão - A penetração de agentes anti-TNF na América Latina é comparável ao resto do mundo na DC, mas menor na RCU. Com o aumento da incidência e prevalência de DII, estratégias específicas para se aumentar o acesso a agentes anti-TNF na RCU e novos agentes biológicos nas DII em geral são justificadas.

DESCRITORES - Doença de Crohn. Colite ulcerativa. Doenças inflamatórias intestinais. Terapia biológica. América Latina. 


\section{REFERENCES}

1. Ng SC, Shi HY, Hamidi N, Underwood FE, Tang W, Benchimol EI, et al. Worldwide incidence and prevalence of inflammatory bowel disease in the 21 st century: a systematic review of population-based studies. Lancet. 2018;390:2769-78

2. Kotze PG, Underwood FE, Damião AOMC, Ferraz JGP, Saad-Hossne R, Toro M, et al. The progression of inflammatory bowel disease throughout Latin America: a systematic review. Clin Gastroenterol Hepatol. 2019. pii: S15423565(19)30668-8.

3. Hanauer SB, Feagan BG, Lichtenstein GR, Mayer LF, Schreiber S, Colombel JF, et al. Maintenance infliximab for Crohn's disease: The ACCENT I randomised trial. Lancet. 2002;359:1541-9.

4. Colombel JF, Sandborn WJ, Rutgeerts P, Enns R, Hanauer SB, Panaccione R, et al. Adalimumab for Maintenance of Clinical Response and Remission in Patient With Crohn's Disease: The CHARM Trial. Gastroenterology. 2007;132:52-65.

5. Rutgeerts P, Sandborn WJ, Feagan BG, Reinisch W, Olson A, Johanns J, et al. Infliximab for induction and maintenance therapy for ulcerative colitis. N Eng J Med. 2005;353:2462-76

6. Sandborn WJ, Colombel JF, D'Haens G, Van Assche G, Wolf D, Kron M, et al One-year maintenance outcomes among patients with moderately-to-severely active ulcerative colitis who responded to induction therapy with adalimumab: Subgroup analyses from ULTRA 2. Aliment Pharmacol Ther. 2013;37:204-13.

7. Feagan BG, Rutgeerts P, Sands BE, Hanauer S, Colombel J-F, Sandborn WJ, et al. Vedolizumab as Induction and Maintenance Therapy for Ulcerative Colitis N Engl J Med. 2013;369:699-710.

8. Sandborn WJ, Feagan BG, Rutgeerts P, Hanauer S, Colombel JF, Sands BE, et al. Vedolizumab as Induction and Maintenance Therapy for Ulcerative Colitis N Engl J Med. 2013;13:711-21.

9. Feagan BG, Sandborn WJ, Gasink C, Jacobstein D, Lang Y, Friedman JR, et al. Ustekinumab as Induction and Maintenance Therapy for Crohn's Disease. N Engl J Med. 2016;375:1946-60.

10. Sandborn WJ, Su C, Sands BE, Dhaens GR, Vermeire S, Schreiber S, et al. Tofacitinib as induction and maintenance therapy for ulcerative colitis. N Engl J Med. 2017:376:1723-36.

11. D'Haens G, Baert F, van Assche G, Caenepeel P, Vergauwe P, Tuynman H, et al. Early combined immunosuppression or conventional management in patients with newly diagnosed Crohn's disease: an open randomised trial. Lancet. 2008;371:660-7.

12. Khanna R, Bressler B, Levesque BG, Zou G, Stitt LW, Greenberg GR, et al. Early combined immunosuppression for the management of Crohn's disease (REACT) A cluster randomised controlled trial. Lancet. 2015;386:1825-34.

13. Colombel J-F, Panaccione R, Bossuyt P, Lukas M, Baert F, Vaňásek T, et al Effect of tight control management on Crohn's disease (CALM): a multicentre, randomised, controlled phase 3 trial. Lancet. 2018;390:2779-89.

14. Kotze PG, Vieira A, Sobrado Junior CW, Salem JB, Kotze LM da S. Adalimumab in the induction of Crohn's disease remission: results of a Brazilian multicenter case series. J Coloproctology. 2011;31:233-240.

15. Kotze PG, Abou-Rejaile VR, Uiema LA, Olandoski M, Sartor MC, Miranda $\mathrm{EF}$, et al. Adalimumab for maintenance therapy for one year in Crohn's disease: results of a Latin American single-center observational study. Arq Gastroenterol 2014;51:39-45.

16. Zacharias P, Damiao AOMC, Moraes AC, Teixeira FV, Ludvig JC, Nones RB, et al. Adalimumab for ulcerative colitis: Results os a Brazilian multicenter observational study. Arq Gastroenterol. 2017;54 321:321--7.

17. Bechara CS, Lacerda Filho A, Ferrari MLA, Andrade DAR, Luz MMP, Silva RG Montreal classification of patient operated for Crohn's disease and identification of surgical recurrence predictors. Rev Col Bras Cir. 2015;42:97-104.

18. Barros KSC, Flores C, Harlacher L, Francesconi CFM. Evolution of Clinical Behavior in Crohn's Disease: Factors Associated with Complicated Disease and Surgery. Dig Dis Sci. 2017;62:2481-8.

19. Rodríguez-Castro KI, Gutiérrez-Ramírez C, Avendaño-Alvarado G. Descripción epidemiológica y tratamiento de los pacientes con enfermedad de Crohn. Acta Méd Costarric. 2013;55:182-7

20. Hano García OM, Andrade Gomes S, Villa Jiménez OM, González Fabián L Wood Rodríguez L. Caracterización de pacientes con enfermedad de Crohn atendidos en el Instituto de Gastroenterología de Cuba - Characterization of patients with Crohn's disease cared for at the Institute of Gastroenterology of Cuba. Rev Cuba Investig Biomédicas. 2014;33:253-67.

21. Silva BC, Lyra AC, Mendes CMC, Ribeiro CPO, Lisboa SRO, de Souza MTL, et al. The Demographic and Clinical Characteristics of Ulcerative Colitis in a Northeast Brazilian Population. Biomed Res Int. 2015;2015:1-8.

\section{(c) BY-NC}

22. De La Cruz-Guillén AA, Cortés-Espinosa T, Sánchez-Chávez X, López Gómez JG, Quintero Aguilar G, Reyes Zermeño MG, et al. Comportamiento clínico de la colitis ulcerosa crónica inespecífica en pacientes del CMn 20 de Noviembre, ISSSte, y comparación con la bibliografía Americana. Med Interna Mex. 2011;27:224-30.

23. Arantes JAV, dos Santos CHM, Delfino BM, da Silva BA, de Souza RMM, de Souza TMM, et al. Epidemiological profile and clinical characteristics of patients with intestinal inflammatory disease. J Coloproctology. 2017;37:273-8.

24. Lima Martins A, Volpato RA, Zago-Gomes M da P. The prevalence and phenotype in Brazilian patients with inflammatory bowel disease. BMC Gastroenterol 2018;18:87.

25. Vivan TK, Santos BM, dos Santos CHM. Quality of life of patients with inflammatory bowel disease. J Coloproctology. 2017;37:279-84

26. Lima CA, Lyra AC, Mendes CMC, Lopes MB, Coqueiro FG, Rocha R, et al Bone mineral density and inflammatory bowel disease severity. Brazilian J Med Biol Res. 2017;50:1-8.

27. K Kleinubing Júnior H, Pinho MDSL, Ferreira LC, Bachtold GA, Merki A. Outpatients profile with inflammatory bowel disease. Arq Bras Cir Dig. 2011;24:200-3

28. Simian D, Fluxá D, Flores L, Lubascher J, Ibáñez P, Figueroa C, et al. Inflammatory bowel disease: A descriptive study of 716 local Chilean patients. World J Gastroenterol. 2016;22:5267-75.

29. Baños FJ, Vélez MHR, Arango JFF, Gómez JHD, Zuluaga JIM, Arango CM, et al. Phenotypes and natural history of Inflammatory Bowel Disease (IBD) in a referral population in Medellín, Colombia. Rev Colomb Gastroenterol. 2010;25:240-51.

30. Yamamoto-Furusho JK, Sarmiento-Aguilar A. Mild clinical behaviour of Crohn disease in elderly patients in a Latin American country: A case-control study. Can J Gastroenterol Hepatol. 2015;29:435-9.

31. Yamamoto-Furusho JK. Clinical epidemiology of ulcerative colitis in Mexico: A single hospital-based study in a 20-year period (1987-2006). J Clin Gastroenterol. 2009;43:221-4.

32. Yamamoto-Furusho J, Sarmiento A, Toledo-Mauriño J, Bozada-Gutiérrez K, Bosques-Padilla, Martínez-Vázquez FM, et al. Clinical and sociodemographical characteristics of inflammatory bowel disease in Mexico : Multicentric nation - wide study ( EPIMEX - IBD ). Poster presentation P839. ECCO congress 2018

33. Mendez JP, Moreno GO, Plata ALMR, Molina LL, Ordoñes KA, Gamio JLA, et al. Caracteristicas epidemiologicas y clinicas de la enfermedad inflamatoria intestinal en un hospital de referencia de Lima-Peru. Rev Gastroenterol Peru. 2016;36:209-18

34. Melendez J, Larregui Y, Vazquez J, Carlo V, Torres E. Medication profiles Puerto Rico IBD. P R Health Sci J. 2011;30:3-8.

35. Luciano MJ, Noria A, Iade B. P688 Demographic, clinical, and therapeutic characteristics of a cohort of 238 patients with ulcerative colitis from two medical centres from Uruguay. J Crohn's Colitis. 2018;12(Suppl1):S458-9.

36. Danese S, Vuitton L, Peyrin-Biroulet L. Biologic agents for IBD: Practical insights. Nat Rev Gastroenterol Hepatol. 2015; 2:537-45.

37. Chan $\mathrm{HC}$ hey, $\mathrm{Ng} \mathrm{SC}$. Emerging biologics in inflammatory bowel disease. J Gastroenterol. 2017;52:141-150.

38. Harbord M, Eliakim R, Bettenworth D, Karmiris K, Katsanos K, Kopylov U, et al. Third European Evidence-based Consensus on Diagnosis and Management of Ulcerative Colitis. Part 2: Current Management. J Crohn's Colitis. 2017;11: 769-84.

39. Gomollón F, Dignass A, Annese V, Tilg H, Van Assche G, Lindsay JO, et al. 3rd European evidence-based consensus on the diagnosis and management of Crohn's disease 2016: Part 1: Diagnosis and medical management. J Crohn's Colitis. 2017;11:3-25.

40. Scheinberg M, Pineda C, Castañeda-Hernández G, Zarbá JJ, Damião A, Arantes $\mathrm{LH}$, et al. Biosimilars in oncology and inflammatory diseases: current and future considerations for clinicians in Latin America. mAbs. 2018;10:827-42.

41. Perin RL, Damião AOMC, Flores C, Ludvig JC, Magro DO, Miranda EF, et al. Vedolizumab in the management of inflammatory bowel diseases: a Brazilian observational multicentric study. Arq Gastroenterol. 2019;56:312-7.

42. Flores C, Zacharias P, Perin R, Nones R, Loures M, Teixeira F, et al. Vedolizumabe na indução da remissão na Retocolite Ulcerativa: Um estudo piloto observacional e multicêntrico. Arq Bras Cir Dig Express. 2018;28(Suppl 5):1153.

43. Parra Izquierdo V, Cifuentes Amortegui S, Avendaño RS, Ponce de Léon E, Flórez C, Reyes Medina G, et al. P183 Colombian real-world experience of vedolizumab use in patients with inflammatory bowel disease-EXVEDOCOL. Poster presentation P183, ECCO congress 2019.

44. Parra RS, Feitosa MR, Féres O, Ribeiro da Rocha JJ, Chebli JMF, Chebli L, et al. P460 Efficacy of ustekinumab in patients with anti-TNF refractory Crohn's disease: data from a real-world study in Brazil. J Crohn's Colitis. 2019;13(Suppl 1):S341-2. 